\title{
PEREKONOMIAN INDONESIA
}

REVIEW JOURNAL

“BOOSTING INDONESIA'S TOURISM SECTOR TO BE COMPETITIVE"

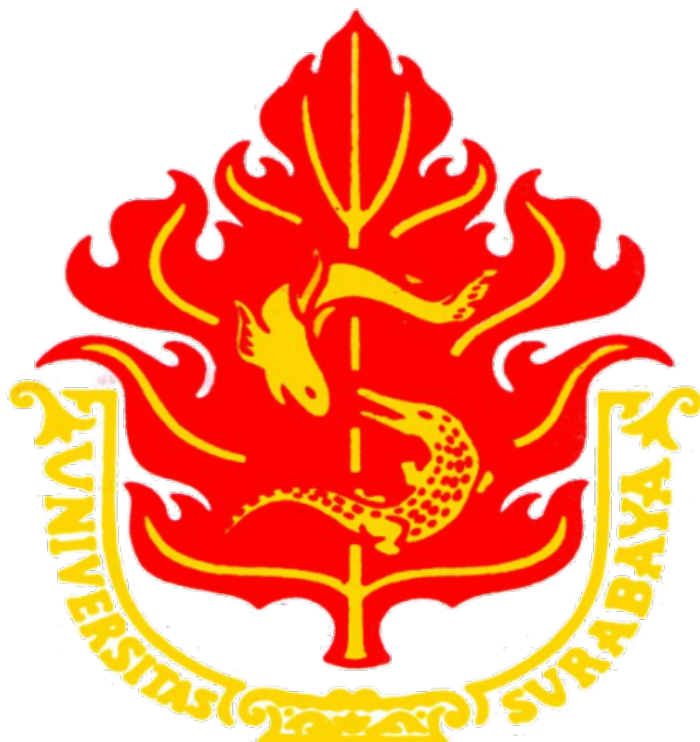

KP B

Meliani Rosanty

130218294

KP B

FAKULTAS BISNIS DAN EKONOMIKA (FBE)

UNIVERSITAS SURABAYA 


\section{REVIEW JOURNAL}

\section{BOOSTING INDONESIA'S TOURISM SECTOR TO BE COMPETITIVE}

Oleh

:- Ahmad Zafrullah Tayibnapis

- Made Siti Sundari

Sumber Website : https://scholar.google.com

\section{REVIEW}

Sektor pariwisata menjadi sektor penghasil devisa utama Indonesia yang diharapkan oleh pemerintah untuk menutupi defisit pada transaksi berjalan, meningkatkan lapangan kerja, dan mengembangkan UMKM masyarakat. Hal ini dikarenakan sektor pariwisata memiliki dampak langsung dan tidak langsung terhadap perekonomian domestik. Pengembangan pada sektor pariwisata sendiri secara tidak langsung dapat menyerap banyak tenaga kerja sehingga dapat meningkatkan pertumbuhan ekonomi. Selain itu, sektor pariwisata secara langsung juga dapat meningkatkan aliran modal masuk ke Indonesia.

Namun, terdapat berbagai kendala yang menyebabkan indeks daya saing pariwisata Indonesia menjadi rendah terutama dalam hal ketersediaan teknologi informasi, komunikasi dan layanan infrastruktur. Selain itu, terdapat masalah lain yang dapat mengurangi daya saing pariwisata Indonesia seperti masalah kesehatan, keamanan yang rentan terhadap kejahatan dalam transaksi, dan harga tiket penerbangan domestik yang lebih mahal dibanding harga tiket penerbangan internasional. Sebenarnya sektor pariwisata Indonesia sendiri sudah memiliki beberapa keunggulan, salah satunya adalah harganya yang lebih kompetitif dibandingkan negara lainnya. Namun, adanya keterbatasan anggaran untuk promosi sehingga harga yang kompetitif tidak dikomunikasikan dengan baik kepada wisatawan asing.

Dalam rangka mewujudkan Indonesia sebagai tujuan wisata terkemuka, pemerintah meluncurkan 6 program yang akan mengembangkan 5 tujuan wisata terkemuka seperti Danau Toba di Sumatera Utara, Borobudur di Jawa Tengah, Labuan Bajo di Nusa Tenggara Timur, Mandalika di Nusa Tenggara Barat, dan Likupang di Sulawesi Utara. Pemerintah juga telah menetapkan target 21,6 juta pengunjung luar negeri pada tahun 2020 dan 31,8 juta pada tahun 2025. Dalam merealisasikan program tersebut, pemerintah menyediakan anggaran 
sebesar Rp 9,34 triliun pada tahun 2020 untuk membangun infrastruktur seperti jalan, jembatan, hotel, dsb.

\section{SARAN}

Menurut saya, penulisan jurnal ini sangat bermanfaat sekali untuk membuka wawasan pembaca bahwa sektor pariwisata sangat berperan penting terhadap perekonomian negara. Oleh karena itu, sebagai masyarakat Indonesia kita juga perlu ikut serta membantu pemerintah dalam mengembangkan sektor pariwisata Indonesia. Hal ini dapat kita mulai dengan menjaga lingkungan di sekitar tempat wisata yang kita kunjungi dan menghormati kebudayaan serta nilai-nilai yang ada. Meskipun terbilang biasa, namun hal ini dapat berdampak besar terhadap citra pariwisata itu sendiri. Jurnal ini juga sangat membantu pembacanya karena penjelasannya yang jelas serta mengajikan informasi yang valid. Selain itu, topik pada jurnal ini sangat menarik untuk dibahas karena topik ini berkaitan langsung dengan perekonomian Indonesia. Oleh karena itu, jurnal ini sangat bagus untuk dibaca karena dapat meningkatkan wawasan pembaca mengenai pentingnya pengembangan pada sektor pariwisata yang kadang kita tidak sadari potensinya. Namun, sebaiknya jurnal ini juga dibuat dalam versi Indonesianya, karena masih ada banyak pembaca yang masih kurang fasih berbahasa Inggris. Selain itu, tulisan dari jurnal juga terlalu kecil sehingga agak sulit untuk dibaca.

\section{KESIMPULAN}

Kesimpulan yang saya dapatkan dari jurnal ini bahwa sektor pariwisata merupakan sektor yang berperan penting bagi Perekonomian Indonesia. Hal ini dikarenakan sektor pariwisata dapat menutupi defisit pada transaksi berjalan dan anggaran negara. Meskipun secara alami Indonesia memiliki potensi sumber daya alam dan budaya yang besar. Namun, terdapat berbagai kendala yang menyebabkan indeks daya saing pariwisata Indonesia menjadi rendah seperti ketersediaan teknologi informasi, komunikasi dan layanan infrastruktur yang kurang efektif. Sehingga diperlukan program khusus dari pemerintah untuk mengembangkan sektor pariwisata tersebut agar memiliki daya saing yang tinggi. 